\title{
HOTS AND E-LEARNING OF DIPLOMA AND UNDERGRADUATE: ILMIZI MODEL FOR ENVIRONMENTAL DISASTER MITIGATION EDUCATION DURING NEW NORMAL COVID-19
}

\author{
ILMI ZAJULI ICHSAN*, AGUNG PURWANTO AND HENITA RAHMAYANTI
}

Department of Population and Environmental Education, Universitas Negeri Jakarta, Rawamangun Muka Street, East Jakarta, 13220, Indonesia.

*Corresponding author: ilmi.z.ichsan@gmail.com

Submitted final draft: 21 February 2021 Accepted: 28 March 2021

http://doi.org/10.46754/jssm.2021.06.001

\begin{abstract}
Innovation in learning is a necessity for environmental learning in 21 st century especially during the new normal era of the Coronavirus Disease 2019 (COVID-19). One of important skills to address disaster mitigation issue is Higher Order Thinking Skills (HOTS) that can be trained using the Innovation Learning Model for Natural Science and Environmental Learning (ILMIZI) model regarding e-learning. This research aims to measure HOTS and descriptively analyse the e-learning and ILMIZI model. The research method is descriptive with survey as the data collection technique. The total sample size of this research were 176 students divided into 105 diploma students and 71 undergraduate students. The results show a very low HOTS score of students at the diploma (30.98) and undergraduate (32.02) level regarding disaster mitigation concepts. This study also considered the dominant use of Power Point file (41.38\%), distractions in e-learning related to phone signals $(44.83 \%)$, and the study discovered that majority of students feel more independent in learning $(62.07 \%)$. The descriptive analysis indicates that the ILMIZI model is compatible for use in environmental learning concerning disaster mitigation. It is the finding of this research that student's HOTS scores are still low; the implementation of e-learning programmes faces some obstacles; and the ILMIZI model is suitable for environmental learning as a means of disaster mitigation.
\end{abstract}

Keywords: HOTS, ILMIZI, disaster mitigation.

\section{Introduction}

Education amid a pandemic requires an adjustment in various aspects. One of the aspects is the implementation of physical distancing policy during Coronavirus Disease 2019 (COVID-19) pandemic. The policy prevailed as efforts to keep a distance from each other is vital to prevent COVID-19 transmission (Bashyam \& Feldman, 2020; Tian et al., 2020). This has triggered a shift in learning systems from faceto-face to online learning (e-learning). The use of long-distance learning systems via Internet will change its implementation (Golitsyna, 2017; Leeuw et al., 2016; Xia, 2017). In turn, this will result in several changes to the teaching materials and learning media used, evaluation of learning objectives and other aspects. Moreover, this affects environmental learning that requires various adjustments, especially for environmental disaster mitigation.
Disaster mitigation demands Higher Order Thinking Skills (HOTS) as a means of learning in the new normal era of COVID-19 (Rahmayanti, Ichsan, Azwar, Purwandari, et al., 2020) as it is a topic that involves skills to analyse problems, evaluate them, and create a solution (Onuma et al., 2017; Tsai et al., 2015). Issues such as environmental pollution require the use of mitigating processes. The mitigation process requires the use of HOTS since disaster mitigation is a complicated issue to resolve. Improving HOTS can be carried out by the use of better teaching materials, newer learning media and more innovative, holistic learning models among other things (Abidinsyah et al., 2019; Churcher et al., 2014; Hugerat \& Kortam, 2014; Husamah et al., 2018). One of recommended learning models is known as the Innovation Learning Model for Natural Science 
and Environmental Learning (ILMIZI) model (Ichsan, 2019). The syntax of ILMIZI involves

(1) Identifying the Problem

(2) Limiting the Problem

(3) Making a Mind Map

(4) Interpreting Results

(5) Analysing Results

(6) Interaction and Evaluation.

The model, however, has not been implemented further in several contexts related to disaster mitigation education efforts.

Numerous studies have been done on HOTS especially those relating to students' HOTS profiles at various levels of education. The results of these previous studies suggest that the students' HOTS score were low (Ichsan et al., 2019, 2020; Zohar \& Agmon, 2018) Junior High School. In addition, HOTS test questions developed to measure students' skills in the context of environment related to COVID-19 indicated that the HOTS score in this area was also low (Ichsan \& Rahmayanti, 2020) especially to solve environmental problems when COVID-19 pandemic. This was to develop a new level of thinking, namely Higher Order Thinking Skills of Environmental Problem (HOTSEP). Other studies concerned the development of a learning model to improve HOTS (Husamah et al., 2018; Rahmayanti, Ichsan, Azwar, Purwandari, et al., 2020). Additional, effort to develop HOTS started with media utilisation and has since moved to changes in education curriculum (Garcia, 2015; Miarsyah et al., 2019; Sigit et al., 2019; Teimourtash \& Moghaddam, 2017; Vidergor, 2018). Studies on ILMIZI model have been previously conducted and the model is recommended to enhance students' HOTS (Ichsan, 2019). ILMIZI potentially improve HOTS because it has syntax to analyse and evaluate problems, in this case the problem of environmental pollution.

HOTS is a skill that must be improved using e-learning, especially now given the current COVID-19 pandemic situation. Especially for students at the diploma and undergraduate levels. This is because at this level students in the younger generation can create an impact in the community. Innovation and technology-based education is necessary during the COVID-19 pandemic for students at the diploma and undergraduate levels (Allo, 2020; Crawford et al., 2020). This is due to the difficulty of providing access to content in the classroom directly. This encourages the need of utilise technology as a medium of learning. Consequently, the development of teaching materials and learning media should be based on technology, especially in relation to mitigating the effects of the COVID-19 pandemic. It can be said that the research is urgently needed. This research paper aims to describe students' HOTS related to disaster mitigation to prevent environmental pollution, describe the ILMIZI and e-learning effort undertaken in support of environmental learning during the new normal of the COVID-19 pandemic.

\section{Method}

The method used to conduct the research was descriptive with data collection done by way of a survey. The total sample size of this research was 176 students, which consists of 105 diploma students and 71 undergraduate students selected by way of simple random sampling. The research period for this paper was from November 2020 to February 2021.

The research made use of HOTS test questions that consisted of three aspects and six indicators. The aspects were related to HOTS according to Anderson et al (2001) that consist of Analysis, Evaluation, and Creation. The indicators and instruments items were developed to measure HOTS especially in relation to knowledge of environmental disaster mitigation processes. The instrument indicator of the HOTS questions are listed in Table 1. 
Table 1: Instrument indicators of HOTS in disaster mitigation

\begin{tabular}{clc}
\hline No. & \multicolumn{1}{c}{ Indicators } & Item \\
\hline 1 & $\begin{array}{l}\text { Analyze the causes of flooding and recycle habits in the context of disaster } \\
\text { mitigation }\end{array}$ & 1,2 \\
2 & Analyze the impacts of lack of disaster mitigation efforts for river pollution & 3,4 \\
3 & Evaluate disaster mitigation programs to support sustainable development in & 5,6 \\
& urban areas & 7,8 \\
4 & Give criticism regarding the use of plastic that has impacts on disasters & 9,10 \\
5 & Create innovative ideas so that environmental impact analysis can be used to & \\
& solve environmental disaster mitigation issues & 11,12 \\
\hline
\end{tabular}

\section{Validity and Reliability of Instruments}

The results of validity test using Pearson's product moment for the validity and reliability of instruments showed that there was an implied correlation and that the score for all items had significant meaning and that all items were valid. The reliability calculations derived using a split half (Spearman Brown) indicated a value of 0.83 ; which confirmed that the instrument was reliable for use.

As all instruments were valid and reliable, students' HOTS measurements can be conducted following a HOTS score interpretation using categories as outlined in this study. The students' HOTS score is divided into several categories, namely: "very high", "high", "moderate", "low", and "very low". This categorisation aims to facilitate the measurement of students' HOTS. The score categories are indicated in Table 2 below.

Table 2: Categories of students' HOTS score

\begin{tabular}{ll}
\hline \multicolumn{1}{c}{ Category } & \multicolumn{1}{c}{$\begin{array}{c}\text { Interval of Students } \\
\text { HOTS Score }\end{array}$} \\
\hline Very high & $\mathrm{X}>81.28$ \\
High & $70.64<\mathrm{X} \leq 81.28$ \\
Moderate & $49.36<\mathrm{X} \leq 70.64$ \\
Low & $38.72<\mathrm{X} \leq 49.36$ \\
Very low & $\mathrm{X} \leq 38.72$ \\
\hline
\end{tabular}

Source: Categories and interval scores are adopted from Ichsan et al. (2019)
Regarding the identification of students' opinion on the utilisation of e-learning a followup survey was carried out that involved 87 other students. Various aspects asked were related to media, type of file, and duration of e-learning. In addition, the questions provided also concerned about type of connection, disturbances, and type of device used.

Besides the e-learning survey, further analysis was carried out about the ILMIZI learning model in relation to environmental learning for disaster mitigation. The analysis was related to learning activities when the ILMIZI model was applied.

\section{Results and discussion}

The research results signified that the students' HOTS score was still in the "very low" category. This was due to the lack of disaster mitigation learning at the diploma and undergraduate level. The lowest HOTS score was in the seventh item, which was carrying plastic bag as a food container (refer to Table 3).

The research results indicated that the students' HOTS score based on each indicator were varied. In the diploma level, the lowest score was obtained in the fourth indicator, which was give criticism on plastic utilisation.

At the undergraduate level, however, the lowest score was in the third indicator that related to evaluation of sustainable development programmes (see Table 4). 
Table 3: Score of students' HOTS on disaster mitigation for each item

\begin{tabular}{|c|c|c|c|}
\hline No. & Item & Diploma & Undergraduate \\
\hline 1 & $\begin{array}{l}\text { Floods that frequently occur in urban areas causes numerous } \\
\text { social and economic disturbances in the communities; provide } \\
\text { your analysis results in this matter }\end{array}$ & 4.63 & 5.35 \\
\hline 2 & $\begin{array}{l}\text { Accumulated garbage in urban areas can be processed as a form } \\
\text { of disaster mitigation. Provide your analysis on the accumulated } \\
\text { garbage }\end{array}$ & 3.64 & 3.80 \\
\hline 3 & $\begin{array}{l}\text { River siltation-related disasters are due to the large amount of } \\
\text { garbage that inhibited water flow. Provide your analysis related } \\
\text { to this matter }\end{array}$ & 3.12 & 3.41 \\
\hline 4 & $\begin{array}{l}\text { Provide an analysis related to environmental impact analysis } \\
\text { functions in environmental disaster mitigation }\end{array}$ & 3.35 & 3.08 \\
\hline 5 & $\begin{array}{l}\text { Give an opinion related to sustainable development program that } \\
\text { is difficult to implement in terms of disaster mitigation }\end{array}$ & 2.70 & 2.65 \\
\hline 6 & $\begin{array}{l}\text { What evaluation the students can do in disaster mitigation to } \\
\text { support sustainable development programs? }\end{array}$ & 2.98 & 2.80 \\
\hline 7 & $\begin{array}{l}\text { Give criticism of people's behavior that refuse to perform } \\
\text { disaster mitigation efforts as they still carry plastic bag as a food } \\
\text { container! }\end{array}$ & 2.55 & 2.61 \\
\hline 8 & $\begin{array}{l}\text { Give criticism and suggestion related to the effectiveness of } \\
\text { paid-plastic policy }\end{array}$ & 2.85 & 3.03 \\
\hline 9 & $\begin{array}{l}\text { Create a solution to overcome the issue of low community } \\
\text { awareness in the environmental disaster mitigation }\end{array}$ & 3.11 & 3.31 \\
\hline 10 & $\begin{array}{l}\text { environmental impact analysis as a way of disaster mitigation } \\
\text { is deemed less effective; provide an innovative idea so that } \\
\text { environmental impact analysis could be effective }\end{array}$ & 2.70 & 2.73 \\
\hline 11 & $\begin{array}{l}\text { Provide an innovative solution so that environmental impact } \\
\text { analysis and other regulations can be implemented for disaster } \\
\text { mitigation }\end{array}$ & 2.62 & 2.72 \\
\hline \multirow[t]{4}{*}{12} & $\begin{array}{l}\text { Create a simple program to increase students' awareness to flood } \\
\text { mitigation }\end{array}$ & 2.92 & 2.93 \\
\hline & Raw Score & 37.17 & 38.42 \\
\hline & Average Score (interval 0-100) & 30.98 & 32.02 \\
\hline & Category & Very Low & Very Low \\
\hline
\end{tabular}

The results suggest that the lowest score Table 5: Students' HOTS score for eachaspect for diploma and undergraduate level was in the evaluation aspect of the HOTS programme. This can be interpreted as most students being unable to provide a proper evaluation or criticisms and suggestions on various environmental issues. The results of the HOTS score for each aspect

\begin{tabular}{clcc}
\hline No & Aspect & Diploma & Undergraduate \\
\hline 1 & Analyze & 3.69 & 3.91 \\
2 & Evaluate & 2.77 & 2.77 \\
3 & Create & 2.84 & 2.92 \\
\hline
\end{tabular}
are presented in Table 5 . 
Table 4: Students' HOTS score for each indicator

\begin{tabular}{clcc}
\hline No. & \multicolumn{1}{c}{ Indicators } & Diploma & Undergraduate \\
\hline 1 & $\begin{array}{l}\text { Analyze the causes of flooding and recycle habits in the context of } \\
\text { disaster mitigation }\end{array}$ & 4.13 & 4.58 \\
2 & $\begin{array}{l}\text { Analyze the impacts of lack of disaster mitigation efforts for river } \\
\text { pollution }\end{array}$ & 3.24 & 3.25 \\
$3 \quad \begin{array}{l}\text { Evaluate disaster mitigation programs to support sustainable } \\
\text { development in urban areas }\end{array}$ & 2.84 & 2.73 \\
$4 \quad \begin{array}{l}\text { Give criticism regarding the use of plastic that has impacts on disasters } \\
5\end{array}$ & $\begin{array}{l}\text { Create innovative ideas so that environmental impact analysis can be } \\
\text { used to solve environmental disaster mitigation issues }\end{array}$ & 2.90 & 2.82 \\
6 & \begin{tabular}{l} 
Create disaster mitigation-related innovative programs \\
\hline
\end{tabular}
\end{tabular}

The research results indicate that most of the students utilised Google Classroom for learning with most of them using PowerPoint to complete the assignments and work, with the average duration of each e-learning session, being between two and three hours a day (see Table 6).

The research results also indicated that most students utilized cellular data plan as their type of connection used for learning and only $34.48 \%$ used WiFi. This was due to the fact that WFi usage fees are relatively more expensive and require a subscription. The cellular data plan, on the contrary, is more practical and has various options. Students mostly experienced some disturbances due to the cellular signal. Type of device used by the majority of the students was android Smartphone (see Table 7).

Table 6: Media, type of file and e-learning duration

\begin{tabular}{lcc}
\hline \multicolumn{1}{c}{ Option } & Total & Percentage \\
\hline Website & Type of Media & \\
WhatsApp & 6 & 6.90 \\
Google Classroom & 21 & 24.14 \\
Zoom Meeting & 48 & 55.17 \\
Other & 3 & 3.45 \\
& 9 & 10.34 \\
PowerPoint (PPT) & Type of File & \\
Image (JPG/PNG) & 36 & 41.38 \\
Video & 3 & 3.45 \\
Word document & 23 & 26.44 \\
PDF document & 14 & 16.09 \\
& 11 & 12.64 \\
1 hr/day & E-Learning Duration & \\
2-3 hrs/day & 26 & 29.89 \\
4-6 hrs/day & 47 & 54.02 \\
$>6$ hrs/day & 13 & 14.94 \\
\hline
\end{tabular}


Table 7: Type of connection, disturbance, and type of device used

\begin{tabular}{lccc}
\hline \multicolumn{1}{c}{ Option } & Total & Percentage \\
\hline Wifi & Type of connection & & \\
Cellular data plan (data/unlimited) & 30 & 34.48 \\
& & 57 & 65.52 \\
Running out of data & Type of disturbance & & \\
Disturbed cellular signal & & 21 & 24.14 \\
Longer Smartphone loading & 39 & 44.83 \\
Disturbed Wifi & & 10 & 11.49 \\
Other & & 13 & 14.94 \\
& & 4 & 4.60 \\
Android Smartphone & Type of Device & & \\
iPhone & & 55 & 63.22 \\
Laptop & & 8 & 9.20 \\
\hline
\end{tabular}

In terms of students learning independence, most students $(62.07 \%)$ agreed that the application of e-learning made them more independent. Most of them also perceived that it was easy for them to understand the content using e-learning although some of them $(33.33 \%)$ were still uncertain about how easy it was to understand the content presented on an e-learning platform (see Table 8).
Based on the research results the students' HOTS scores were "relatively low" in matters relating to disaster mitigation. The students' opinions regarding e-learning were varied and covered everything from the obstacles experienced during e-learning to the aspects of learning independence and ease of understanding the content conveyed by the lecturers. The research results generally

Table 8: Learning independence and easiness in e-learning

\begin{tabular}{|c|c|c|}
\hline Opinion & Total & Percentage \\
\hline \multicolumn{3}{|c|}{ Learning Independence in E-Learning } \\
\hline Strongly agree & 3 & 3.45 \\
\hline Agree & 54 & 62.07 \\
\hline Uncertain & 25 & 28.74 \\
\hline Disagree & 4 & 4.60 \\
\hline Strongly Disagree & 1 & 1.15 \\
\hline \multicolumn{3}{|c|}{ Easiness in Understanding Content } \\
\hline Strongly agree & 1 & 1.15 \\
\hline Agree & 43 & 49.43 \\
\hline Uncertain & 29 & 33.33 \\
\hline Disagree & 11 & 12.64 \\
\hline Strongly Disagree & 3 & 3.45 \\
\hline
\end{tabular}


indicated that e-learning experiences must be improved and its implementation made to work more smoothly and without obstacles in order to improve its utility. In coping with the obstacles, one of learning models that was used was the ILMIZI model. An innovation of the ILMIZI model is an alternative option to overcome various environmental problems. The ILMIZI model implementation can be seen in Table 9 .

The research results implied that the HOTS' score was still very low in terms of disaster mitigation. This was due to the lack of availability of HOTS-based teaching materials and learning media. As consequence, students have difficulties in performing an activity applied to improve the HOTS.

Innovation and development in HOTSrelated teaching materials and learning media require further advancement (Garcia, 2015; Hugerat \& Kortam, 2014; Husamah et al., 2018; Istiyono et al., 2020; Miarsyah et al., 2019; Rahmayanti, Ichsan, Azwar, Damayanti, et al., 2020; Ramadhan et al., 2019; Sigit et al., 2019; Suharini, Ariyadi, et al., 2020; Suharini, Kurniawan, et al., 2020). The goal is to have various alternatives for teachers and lecturers in utilizing the teaching materials.
These teaching materials and learning media variation will facilitate environmental learning and students will become more interested in learning. Students who are active in learning will be better due to discussion and interaction in the learning that brings good impact on the learning quality.

ILMIZI as an environmental learning model that has learning stages that support efforts to elevate interaction and discussion between students. Stages of ILMIZI that can be improve HOTS were in step 3, 5 and 6. Because students train to be create an innovative mind map, then they must analyze and evaluate the problem to be solved.

The discussion between students will talk about disaster mitigation that becomes the learning focus. The activity is observable in the learning stages from the first to the last stage. In addition, the last stage of the ILMIZI model is evaluation activity and e-learning require a variation in media and teaching materials. ILMIZI model in this context is suitable for disaster education because disaster can have many problems to be solved.

Table 9: Learning activities from ILMIZI model in disaster mitigation topic

\begin{tabular}{|c|c|c|c|}
\hline No. & Learning Step & Learning activities & Duration \\
\hline 1 & Identify Problem & $\begin{array}{l}\text { Students were asked by lecturer to identify problems related } \\
\text { to disaster aspects in Indonesia }\end{array}$ & 10 minutes \\
\hline 2 & Limitation Problem & Students limit the disaster mitigation problems & 10 minutes \\
\hline 3 & Make Mind Map & $\begin{array}{l}\text { Students create a mind map related to efforts for disaster } \\
\text { mitigation in urban areas }\end{array}$ & 20 minutes \\
\hline 4 & Interpret Result & $\begin{array}{l}\text { Students interpret the results of the created mind map to make } \\
\text { it easier to observe the flow and solutions of the disaster } \\
\text { mitigation problem solving }\end{array}$ & 15 minutes \\
\hline 5 & Analyze Result & Students analyze the results of the created mind map & 10 minutes \\
\hline 6 & $\begin{array}{l}\text { Interaction and } \\
\text { Evaluate }\end{array}$ & $\begin{array}{l}\text { Students interact with their friends. The interaction is a } \\
\text { question and answer process. An interaction also occurs } \\
\text { between students and lecturers regarding the discussed } \\
\text { disaster mitigation topic. Next, an evaluation carries out } \\
\text { on student skill in understanding the disaster content. The } \\
\text { evaluation is conducted by providing an assessment to fellow } \\
\text { friends and through test questions provided by the lecturers. }\end{array}$ & 20 minutes \\
\hline
\end{tabular}


All disaster mitigation plans can be learned with ILMIZI model because all disasters need analysis to create a workable solution to solve problem. ILMIZI model can help teacher or lecturer to implement the HOTS-based learning.

The teaching materials and learning media developed can take the form of or as a supplement in education (Azrai et al., 2019; Ichsan et al., 2020; Komala et al., 2020; Rahmayanti, Ichsan, Oktaviani, Syani, et al., 2020; Sulistyawati et al., 2019; Suniah et al., 2018). This is in accordance with student needs to supplement in the form of additional content in various environment-related topics. The supplement is felicitous for the $21^{\text {st }}$ century environmental learning as students can procure various additional knowledge during the new normal of COVID 19.

During the new normal, all learning activities are online. This requires the use of online-based teaching materials and media. Various teaching materials and learning media can be developed in the form of e-book with content adjusted to the student needs. For example, an e-book that is a supplement requires broader content than those in the textbooks (Lai, 2016; Purwanto et al., 2020). A supplement book will facilitate students to be more contextual with the current situation and condition (Kartikaningtyas et al., 2018; Paristiowati et al., 2019).

Therefore, the learning will be contextual and relevant to the current state. This situation will assist students to empower their skills in HOTS, especially those related to efforts in improving disaster mitigation education with specific topic in environmental pollution. Another topic such as climate change and global warming can be developed as a learning media innovation with the ILMIZI model.

\section{Conclusion}

The conclusion drawn by this research paper is that the HOTS score of diploma and undergraduate students is "relatively low". This was due to the lack of teaching materials and learning media employed as a learning supplement on disaster mitigation.

Moreover, e-learning application during the new normal of COVID-19 was still experiencing various obstacles. E-learning, however, has some advantages, such as it can share various files and make learning more independent. ILMIZI model was one of innovation can be implement for disaster education during pandemic.

This model has a syntax that can improve HOTS implementation. Suggestions proposed by this research include the need for teaching material or learning media development that functions as a supplement for disaster mitigation.

\section{Acknowledgements}

Thank you for Indonesia Ministry of Education, Culture, Research and Technology (Kementerian Pendidikan, Kebudayaan, Riset dan Teknologi Republik Indonesia) for funding this research in 2021 for Doctoral Dissertation Research Grants.

\section{References}

Abidinsyah, A., Ramdiah, S., \& Royani, M. (2019). The implementation of local wisdom-based learning and HOTSbased assessment: Teacher survey in Banjarmasin. JPBI (Jurnal Pendidikan Biologi Indonesia), 5(3), 407-414. https:// doi.org/10.22219/jpbi.v5i3.9910

Allo, M. D. G. (2020). Is the online learning good in the midst of COVID-19 Pandemic? The case of EFL learners. Jurnal Sinestesia, 10(1), 1-10.

Azrai, E. P., Sigit, D. V., Heryanti, E., Ichsan, I. Z., Jajomi, Y. P., \& Fadrikal, R. (2019). Green consumerism among students: A survey in campus. Journal of Physics: Conference Series, 1317(1), 012200. https:// doi.org/10.1088/1742-6596/1317/1/012200

Bashyam, A. M., \& Feldman, S. R. (2020). Should patients stop their biologic treatment during the COVID-19 pandemic. The Journal of Dermatological Treatment, 
1-2. https://doi.org/10.1080/09546634.202 0.1742438

Churcher, K. M. A., Downs, E., \& Tewksbury, D. (2014). "Friending " Vygotsky: A social constructivist pedagogy of knowledge building through classroom social media use. Journal of Effective Teaching, 14(1), 33-50.

Crawford, J., Butler-Henderson, K., Rudolph, J., \& Glowatz, M. (2020). COVID-19: 20 countries' higher education intra-period digital pedagogy responses. Journal of Applied Teaching and Learning (JALT), 3(1), 1-20. https://doi.org/10.37074/ jalt.2020.3.1.7

Garcia, L. C. (2015). Environmental science issues for higher-order thinking skills (hots) development: A case study in the Philippines. In Biology Education and Research in a Changing Planet (pp. 45-54). https://doi.org/10.1007/978-981-287-524-2

Golitsyna, I. (2017). Educational process in electronic information-educational environment. Procedia - Social and Behavioral Sciences, 237, 939-944. https:// doi.org/10.1016/j.sbspro.2017.02.132

Hugerat, M., \& Kortam, N. (2014). Improving higher order thinking skills among freshmen by teaching science through inquiry. Eurasia Journal of Mathematics, Science and Technology Education, 10(5), 447-454. https://doi.org/10.12973/ eurasia.2014.1107a

Husamah, H., Fatmawati, D., \& Setyawan, D. (2018). OIDDE learning model: Improving higher order thinking skills of biology teacher candidates. International Journal of Instruction, 11(2), 249-264. https://doi. org/10.12973/iji.2018.11217a

Ichsan, I. Z. (2019). ILMIZI: Innovation learning model for natural science and environmental learning based on HOTS. International Journal for Educational and Vocational Studies, 1(6), 578-584. https:// doi.org/10.29103/ijevs.v1i6.1640
Ichsan, I. Z., \& Rahmayanti, H. (2020). HOTSEP: Revised Anderson's Taxonomy in environmental learning of COVID-19. European Journal of Educational Research, 9(3), 1257-1265. https://doi.org/10.12973/ eu-jer.9.3.1257

Ichsan, I. Z., Sigit, D. V., Miarsyah, M., Ali, A., Arif, W. P., \& Prayitno, T. A. (2019). HOTS-AEP: Higher order thinking skills from elementary to master students in environmental learning. European Journal of Educational Research, 8(4), 935-942. https://doi.org/10.12973/eu-jer.8.4.935

Ichsan, I. Z., Sigit, D. V., Miarsyah, M., Ali, A., Suwandi, T., \& Titin, T. (2020). Implementation supplementary book of green consumerism: Improving students hots in environmental learning. European Journal of Educational Research, 9(1), 227-237. https://doi.org/10.12973/eu-jer.9. 1.227

Istiyono, E., Dwandaru, W. S. B., Setiawan, R., \& Megawati, I. (2020). Developing of computerized adaptive testing to measure physics higher order thinking skills of senior high school students and its feasibility of use. European Journal of Educational Research, 9(1), 91-101. https:// doi.org/10.12973/eu-jer.9.1.91

Kartikaningtyas, V., Kusmayadi, T. A., \& Riyadi, R. (2018). The effect of brain based learning with contextual approach viewed from adversity quotient. Journal of Physics: Conference Series, 1022. https:// doi.org/10.1088/1742-6596/1022/1/012014

Komala, R., Lestari, D. P., \& Ichsan, I. Z. (2020). Group investigation model in environmental learning: An effect for students' higher order thinking skills. Universal Journal of Educational Research, 8(4A), 9-14. https:// doi.org/10.13189/ujer.2020.081802

Lai, C. (2016). Integrating E-books into Science teaching by preservice elementary school teachers to cite this article: Integrating E-books into Science teaching by preservice elementary school teachers. Journal of 
Education in Science, Environment and Health, 2(1), 57-66.

Leeuw, R. A. D., Westerman, M., Nelson, E., Ket, J. C. F., \& Scheele, F. (2016). Quality specifications in postgraduate medical e-learning: An integrative literature review leading to a postgraduate medical e-learning model. BMC Medical Education, 16(1), 1-10. https://doi.org/10.1186/s12909-0160700-7

Miarsyah, M., Rusdi, R., Aryani, N. D., \& Ichsan, I. Z. (2019). MEBA: Development androidbased ecosystem module for senior high school students. Indian Journal of Public Health Research and Development, 10(8), 2114-2118. https://doi.org/10.5958/09765506.2019 .02168 .5

Onuma, H., Shin, K. J., \& Managi, S. (2017). Reduction of future disaster damages by learning from disaster experiences. Natural Hazards, 87(3), 1435-1452. https://doi. org/10.1007/s11069-017-2825-3

Paristiowati, M., Hadinugrahaningsih, T., Purwanto, A., \& Karyadi, P. A. (2019). Analysis of students' scientific literacy in contextual-flipped classroom learning on acid-base topic. Journal of Physics: Conference Series, 1156(1), 012026. https:// doi.org/10.1088/1742-6596/1156/1/012026

Purwanto, A., Ichsan, I. Z., Gomes, P. W. P., Rahman, M. M., \& Irwandani, I. (2020). ESBOR during COVID-19: Analysis students attitude for develop 21st century environmental learning. Journal of Sustainability Science and Management, 15(7), 20-29. https://doi.org/10.46754/ jssm.2020.10.003

Rahmayanti, H., Ichsan, I. Z., Azwar, S. A., Damayanti, S., Suharini, E., \& Kurniawan, E. (2020). Environmental learning about flood disaster in university: Students HOTS for preliminary analysis to develop DIFMOL model. E3S Web of Conferences, 211, 02016. https://doi.org/10.1051/ e3sconf/202021102016
Rahmayanti, H., Ichsan, I. Z., Azwar, S. A., Purwandari, D. A., Pertiwi, N., Singh, C. K. S., \& Gomes, P. W. P. (2020). DIFMOL: Indonesian students' hots and environmental education model during COVID-19. Journal of Sustainability Science and Management, 15(7), 10-19. https://doi.org/10.46754/jssm.2020.10.002

Rahmayanti, H., Ichsan, I. Z., Oktaviani, V., Syani, Y., Hadi, W., \& Marhento, G. (2020). Environmental attitude for smart city technology: Need assessment to develop smart trash in environmental education. International Journal of Advanced Science and Technology, 29(3), 8374-8383. http:// sersc.org/journals/index.php/IJAST/article/ view/9872

Ramadhan, S., Mardapi, D., Prasetyo, Z. K., \& Utomo, H. B. (2019). The development of an instrument to measure the higher order thinking skill in physics. European Journal of Educational Research, 8(3), 743-751. https://doi.org/10.12973/eu-jer.8.3.743

Sigit, D. V., Azrai, E. P., Heryanti, E., Ichsan, I. Z., Jajomi, Y. P., \& Fadrikal, R. (2019). Development green consumerism e-book for undergraduate students (gc-ebus) as learning media in environmental learning. Indian Journal of Public Health Research and Development, 10(8), 2026-2031. https:// doi.org/10.5958/0976-5506.2019.02152.1

Suharini, E., Ariyadi, M. H., \& Kurniawan, E. (2020). Google earth pro as a learning media for mitigation and adaptation of landslide disaster. International Journal of Information and Education Technology, 10(11), 820-825.

Suharini, E., Kurniawan, E., \& Ichsan, I. Z. (2020). Disaster mitigation education in the COVID-19 pandemic: A case study in Indonesia. Sustainability (United States), 13(6), 292-298. https://doi.org/10.1089/ sus. 2020.0053

Sulistyawati, A., Indriyanti, D. R., \& Yuniastuti, A. (2019). Development of research-based flowering plants catalog supplement of 
Biology teaching materials in high school. Journal of Innovative Science Education, 8(2), 173-182. https://doi.org/10.15294/ jise.v0i0.27288

Suniah, S., Indriyanti, D. R., \& Dewi, N. K. (2018). Booklet development based research on the diversity of insects on Solanaceae as a supplement of Biology teaching materials in high school. Journal of Innovative Science Education, 7(2), 176-183. https:// doi.org/10.15294/jise.v7i2.24115

Teimourtash, M., \& Moghaddam, M. Y. (2017). On the plausibility of Bloom's higher order thinking strategies on learner autonomy: The paradigm shift. Asian-Pacific Journal of Second and Foreign Language Education, 2(1), 14. https://doi.org/10.1186/s40862017-0037-8

Tian, S., Hu, N., Lou, J., Chen, K., Kang, X., Xiang, Z., Chen, H., Wang, D., Liu, N., Liu, D., Chen, G., Zhang, Y., Li, D., Li, J., Lian, H., Niu, S., Zhang, L., \& Zhang, J. (2020). Characteristics of COVID-19 infection in Beijing. Journal of Infection, 80(4), 401-406. https://doi.org/10.1016/j. jinf.2020.02.018
Tsai, M. H., Wen, M. C., Chang, Y. L., \& Kang, S. C. (2015). Game-based education for disaster prevention. AI and Society, 30(4), 463-475. https://doi.org/10.1007/s00146014-0562-7

Vidergor, H. E. (2018). Effectiveness of the multidimensional curriculum model in developing higher-order thinking skills in elementary and secondary students. The Curriculum Journal, 29(1), 95-115. https:// doi.org/10.1080/09585176.2017.1318771

Xia, B. S. (2017). An In-Depth Analysis of teaching themes and the quality of teaching in higher education: Evidence from the programming education environments. International Journal of Teaching and Learning in Higher Education, 29(2), 245254.

Zohar, A., \& Agmon, V. A. (2018). Raising test scores vs. teaching higher order thinking (hot): Senior science teachers' views on how several concurrent policies affect classroom practices. Research in Science and Technological Education, 36(2), 243260. https://doi.org/10.1080/02635143.201 7.1395332 